\title{
Samhandling for gode pasientforløp i \\ korttidsavdeling på sykehjem
}

\section{Kari Brodtkorb}

Dosent

Institutt for helse- og sykepleievitenskap, Fakultet for helse- og idrettsvitenskap,

Universitetet i Agder, Grimstad

\section{Ragnhild Skaar}

\section{Førstelektor}

Institutt for helse- og sykepleievitenskap, Fakultet for helse- og idrettsvitenskap,

Universitetet i Agder, Grimstad

\section{Åshild Slettebø}

\section{Professor}

Institutt for helse- og sykepleievitenskap, Fakultet for helse- og idrettsvitenskap,

Universitetet i Agder, Grimstad

Observasjonsforskning

\section{Etnografi}

Organisering

Samhandling

Sykehjem

Sykepleien Forskning 202116 (83308) (e-83308)

DOI: 10.4220/Sykepleienf.2021.83308

\section{Sammendrag}

Bakgrunn: Kommunale korttidsavdelinger skal ivareta behovene til pasienter med kompliserte og uavklarte helsetilstander. Forskning viser et behov for å utvikle kapasiteten og kvalitet på tilbudene.

Hensikt: Utforske faktorer som fremmer gode pasientforløp i korttidsavdeling på sykehjem. 
Metode: Studien hadde et etnografisk observasjonsdesign med deltakende observasjon og intervju. Analysen viste fem kategorier og et overordnet tema.

Resultat: Å samhandle om systematikk og flyt i det daglige arbeidet, utvikle tverrprofesjonelt samarbeid, involvere pasient og pårørende, samhandle på tvers av nivåene i helsetjenesten samt maksimere begrensede ressurser var faktorer som fremmet gode pasientforløp.

Konklusjon: Å sikre gode forløp i korttidsavdelinger er krevende, og begrensede ressurser synes å være en kritisk faktor. Samhandlende innsats fra en rekke aktører er nødvendig for å fremme gode pasientforløp.

Politiske og strukturelle reformer påvirker helsetjenestene internasjonalt (1) og nasjonalt (2). Endringene skyldes et behov for mer kompleks helsehjelp til en aldrende befolkning, nedgang i antall sykehussenger og kortere liggetid på sykehus (3).

Siden samhandlingsreformen ble innført (2), har kommunene fått $\varnothing \mathrm{kt}$ pasientgjennomstrømning og behandlingsansvar. Det har medført ulike korttidstilbud (4) og differensierte tilbud (5) på sykehjemmene. Noen kommuner har lyktes (6), men forskning tyder på at det er utfordringer knyttet til kapasitet, organisering og kvalitet (7-11).

Dagens helsetjenester betegnes som et komplekst system under press $(10,12)$ med mange overganger i et pasientforløp (9). Pasientenes sammensatte behov krever sammensatt kompetanse og tjenester på flere nivåer. Det forventes effektivisering samtidig som at kvaliteten bevares og bedres, samt at nye organisatoriske løsninger utvikles (12).

Ingstad (13) hevder at helse- og omsorgstjenestene må være innovative for å løse utfordringene. Fremfor å gjøre mer og arbeide raskere må nye arbeidsmetoder eller samarbeidsformer innføres. 
Allen (14) beskriver sykepleieres sentrale rolle knyttet til organisering av pasientforl $ø$. Mens den direkte pasientomsorgen er pasientfokusert og sykepleieledelse er enhetsfokusert, er organiseringsarbeid rettet mot styring av pasientforløp. I organisasjoner under utvikling er pasientforløpene gjerne komplekse, noe som gjenspeiles i arbeidet med å organisere dem.

Gode pasientforløp karakteriseres av å være sammensatt og koordinert slik at de fremmer samhandling, pasientsikkerhet og pasienttilfredshet og sikrer effektiv ressursutnyttelse (9).

Det er imidlertid behov for mer kunnskap om utviklingen av gode pasientforløp innen de enkelte helse- og omsorgstjenestene $(4,5,9)$ og for forbedringsarbeid for helhetlige, koordinerte og enklere pasientforløp (4). Det vil kunne bidra til å gjøre endringsarbeidet som pågår i tjenestene, kunnskapsbasert og hensiktsmessig.

\section{Hensikten med studien}

Hensikten med denne studien var derfor å utforske faktorer som fremmer gode pasientforløp i korttidsavdeling på sykehjem. Studien var del av et større prosjekt som omhandlet sosial innovasjon på sykehjem.

Der var et vesentlig funn å skape gode pasientforløp, som sammen med tidligere forskning dannet grunnlaget for følgende forskningsspørsmål: Hvilke organisatoriske faktorer fremmer gode pasientforløp i korttidsavdeling på sykehjem?

\section{Metode}

Studien hadde et etnografisk observasjonsdesign med observasjoner og intervjuer ved to sykehjem i en norsk kommune. Sykehjemmene deltok i det NFR-finansierte forskningsprosjektet «Sosial innovasjon i sykehjem» (tildelingsnummer 256647), og ble valgt fordi de var eksempelsykehjem kjent for innovasjon og god kvalitet. 
For å imøtekomme intensjonen med samhandlingsreformen ble tre langtidsavdelinger på de to sykehjemmene i 2014 omgjort til korttidsavdelinger med til sammen 29 senger. Lege- og sykepleiedekningen ble styrket, og avdelingene fikk fysioterapi- og ergoterapitjenester.

Omorganiseringen innebar store endringer i funksjons- og ansvarsområdet for pleiepersonalet. Endringene fordret et betydelig innovasjonsarbeid, som hadde pågått i tre år da prosjektet startet.

Korttidsavdelingene ga et medisinsk og rehabiliterende tilbud, der to senger var for kommunal øyeblikkelig hjelp.

Pasientene kom fra sykehus for medisinsk oppfølging og/eller rehabilitering eller fra hjemmet for utredning og/eller behandling av helsetilstand, justering av hjelpebehov eller avlastning. Oppholdet var tidsbegrenset med variasjon fra dager til måneder, vanligvis mellom to og fire uker.

Avdelingene hadde fagledere (sykepleiere) som delte sin tid likt mellom ledelse og klinisk arbeid. Noen sykepleiere hadde videreutdanninger som kreft- eller intensivsykepleie. Hver institusjon hadde sykehjemslege i 100 prosent stilling. Fysioterapeuter og ergoterapeuter var lokalisert utenfor sykehjemmet.

\section{Metodisk tilnærming}

Den metodiske tilnærmingen var hovedsakelig deltakende observasjon (15). For å få utdypende data gjennomførte vi også intervjuer med institusjonslederne.

Første- og andreforfatteren gjennomførte intervjuer og observasjoner. Observasjonene foregikk over en periode på 16 måneder fra høsten 2016 til høsten 2018, totalt 320 timer. Vi brukte en observasjonsguide som var utviklet fritt etter Polit og Beck (15). 
I observasjonsnotatene konsentrerte vi oss om hendelser og samtaler som samhandling mellom personalet og pasientene i ulike situasjoner og faglige møter og rapporter. For å synliggjøre aktørenes aktivitet var guiden strukturert slik at det fremkom hvem som deltok, og hvilken rolle aktørene hadde. I tillegg ble teoretiske, metodiske og personlige refleksjoner notert.

Til intervjuene utviklet vi en guide strukturert rundt beskrivelse av sykehjemmet, eksempler på innovasjon, innovasjonsprosesser, innovasjonskompetanse og betingelser for innovasjon.

Vi tok feltnotater direkte og redigerte dem i etterkant eller skrev dem så kort tid etter hendelsen som mulig. Forskerrollen varierte fra nøytralt observerende til mer deltakende, og referat fra samtaler med ulike aktører inngår i datamaterialet. Intervjuene ble tatt opp og skrevet ut verbatimt.

\section{Dataanalysen}

Dataene ble analysert i tråd med Graneheim og Lundman (16). Først leste alle feltnotatene i sin helhet hver for seg, etterfulgt av en felles gjennomlesning der aktuelle data for denne studien ble skilt ut.

Så foretok vi en koding av meningsenheter, som deretter ble strukturert til underkategorier.

Underkategoriene ble slått sammen til fem kategorier, og et overordnet tema fremkom. Analysen resulterte i følgende kategorier:

- Samhandle om systematikk og flyt i det daglige arbeidet

- Utvikle tverrprofesjonelt samarbeid

- Involvere pasient og pårørende

- Samhandle på tvers av nivåene i helsetjenesten

- Maksimere begrensede ressurser 
Kategoriene utgjorde til sammen det overordnede temaet Samhandling fremmer gode pasientforløp (tabell

1).

Tabell 1. Eksempler på analysetrinn

\begin{tabular}{|c|c|c|c|}
\hline Kodet meningsenhet & Underkategori & Kategori & Tema \\
\hline $\begin{array}{l}\text { Pleiepersonalet møtes daglig etter morgenstellet for å } \\
\text { planlegge resten av dagen med utgangspunkt i matriseor- } \\
\text { ganisert tavle som synliggjør sentrale elementer i de ulike } \\
\text { pasientenes forløp. }\end{array}$ & $\begin{array}{l}\text { Daglige } \\
\text { tavlemøter }\end{array}$ & $\begin{array}{l}\text { Samhandle om } \\
\text { systematikk og flyt } \\
\text { i det daglige arbeidet }\end{array}$ & \multirow{5}{*}{$\begin{array}{l}\text { Samhandling } \\
\text { fremmer gode } \\
\text { pasientforl } \varnothing p\end{array}$} \\
\hline $\begin{array}{l}\text { Ukentlig tverrfaglig møte i avdelingen der fagleder, lege, fysio- } \\
\text { terapeut, ergoterapeut, sykepleier fra innsatsteam for hverdags- } \\
\text { rehabilitering og representant fra tjenestekontoret deltok. }\end{array}$ & $\begin{array}{l}\text { Samarbeids- } \\
\text { struktur }\end{array}$ & $\begin{array}{l}\text { Utvikle tverr- } \\
\text { profesjonelt } \\
\text { samarbeid }\end{array}$ & \\
\hline $\begin{array}{l}\text { Sykepleier blir oppringt av pårørende til en pasient som er } \\
\text { tiltakende ust } \varnothing \text { og har hatt et fall. Hun redegjør for pasientens } \\
\text { situasjon og informerer om at legen skal se til pasienten. }\end{array}$ & $\begin{array}{l}\text { Involvering } \\
\text { på daglig basis }\end{array}$ & $\begin{array}{l}\text { Involvere pasient } \\
\text { og pårørende }\end{array}$ & \\
\hline $\begin{array}{l}\text { Legen konsulterer ulike spesialister på sykehuset angående } \\
\text { den medisinske behandlingen av enkeltpasienter. }\end{array}$ & $\begin{array}{l}\text { Samhandling } \\
\text { med sykehuset }\end{array}$ & $\begin{array}{l}\text { Samhandle på tvers av } \\
\text { nivåene i helsetjenesten }\end{array}$ & \\
\hline $\begin{array}{l}\text { Fysioterapitjenesten var begrenset og lokalisert utenfor } \\
\text { avdelingen, noe som skapte utfordringer med hensyn til } \\
\text { oppfølging og kontinuitet for pasienter på rehabiliterings- } \\
\text { opphold og for samhandlingen med avdelingens personale. }\end{array}$ & $\begin{array}{l}\text { Møte for å belyse } \\
\text { utfordringene og } \\
\text { søke mulige } \\
\text { løsninger }\end{array}$ & $\begin{array}{l}\text { Maksimere } \\
\text { begrensede } \\
\text { ressurser }\end{array}$ & \\
\hline
\end{tabular}

Prosjektet ble tilrådd av Norsk senter for forskningsdata (NSD). Ledelsen ga skriftlig informert samtykke til å delta i studien. Vi informerte ledelsen og de ansatte om studien i dialogmøte i forkant og underveis. De var innforstått med at det foregikk feltarbeid, og at de kunne reservere seg mot å delta. Pasienter, pårørende og andre ble informert gjennom oppslag på avdelingene.

\section{Resultater}

I det følgende presenterer vi kategoriene og det overordnede temaet.

\section{Samhandle om systematikk og flyt i det daglige arbeidet}

Systematikk i det daglige arbeidet i avdelingen var vesentlig for å skape arbeidsflyt og derigjennom pasientsikkerhet, pasientflyt og gode pasientforløp. Til den $1 \varnothing$ pende kartleggingen under oppholdet hadde personalet anskaffet tavle som visualiserte pasientenes forløp og skapte oversikt. 
Pleierne uttrykte at daglige tavlemøter bidro til felles vurderinger, og at ernæringskartlegging og bruk av sjekklister medførte nye og tettere samhandlingsmønstre. Feltnotatene viste at legen og sykepleierne samarbeidet tett om medisinsk behandling, legemiddelgjennomgang og behandlingsavklaring.

I samtaler uttrykte de at slike former for systematikk bevisst var arbeidet frem etter at avdelingene ble omgjort til korttidsavdelinger. De sa også at det hadde vært krevende, men lærerikt for personalet, som var vant til arbeidsrytmen på langtidsavdeling.

I intervjuet sa en leder følgende: «Vi måtte snu fort fra langtid til korttid uten tid til å forberede personalgruppa. Det var en utfordrende prosess.»

I ukentlige tverrfaglige møter ble pasientenes situasjon gjennomgått av fagleder, lege, fysioterapeut, ergoterapeut, sykepleier fra innsatsteam for hjemmerehabilitering samt en representant for søknadskontoret.

Halvveis i oppholdet var det samarbeidsmøte mellom pasienten, de pårørende og relevante fagpersoner og instanser. Før pasientene reiste hjem, hadde ansatte på avdelingen møte med hjemmesykepleien.

\section{Utvikle tverrprofesjonelt samarbeid}

Ved omgjøringen til korttidsavdelinger ansatte hvert sykehjem en lege på fulltid. Ut over å være ansvarlig for det medisinske tilbudet var legene fullverdige medlemmer av det tverrfaglige teamet, og vi observerte at de engasjerte seg bredt $\mathrm{i}$ institusjonenes virksomhet.

Legene og faglederne hadde et særlig tett og tillitsbasert samarbeid, noe de selv ga uttrykk for, og som ble observert. I sin kombinerte utøvende og ledende rolle opplevde faglederne å få god oversikt over prosesser i avdelingen og bli dypt involvert i pasientenes forløp. 
Fysioterapeuter og ergoterapeuter fulgte opp

avdelingens pasienter på bes $\varnothing$ ksbasis og etter behov, ofte i nært samarbeid med primærkontakten og annet pleiepersonale.

\section{«Med mange aktører involvert var det behov for en samarbeidsstruktur.»}

Med mange aktører involvert var det behov for en samarbeidsstruktur. I likhet med de daglige pleiemøtene ble tverrfaglige møter organisert som tavlemøter, der situasjonen til hver enkelt pasient ble gjennomgått og videre forløp skissert.

Ansatte uttrykte at de hadde et godt samarbeidsklima, og i de tverrfaglige møtene var deltakerne aktive, lyttende, saklige og konstruktive. Når det var tilløp til utfordringer i samarbeidet, fors $\varnothing$ kte de å forebygge konflikter gjennom brobyggende tiltak og minnelige løsninger.

For eksempel arrangerte de dialogmøte da det oppsto utfordringer i samarbeidet med fysioterapitjenesten: «Fagleder gir uttrykk for at fysioterapitjenesten ikke i tilstrekkelig grad prioriterer kontinuitet i sykehjemmet [...] Terapeutene ser at her har de et forbedringspotensial» (feltnotater).

I møtet kom det frem at utfordringen hadde sammenheng med den totale kapasiteten i kommunen, men partene avtalte ulike tiltak som ville kunne bedre situasjonen.

\section{Involvere pasient og pårørende}

Samarbeidet mellom pasienter og ansatte var fundamentalt, mangfoldig og utfordrende. Ansatte involverte pasienter og pårørende både på daglig basis og i planlagte møter. Vi observerte en gjennomgående involverende og dialogbasert tilnærming $\mathrm{i}$ samhandlingen mellom pleiere og pasienter i situasjoner med personlig hygiene og måltider. 
Legene involverte systematisk pasienter i spørsmål om medisinsk behandling og behandlingsavklaring. Vi så en tett interaksjon mellom pasienten og fysioterapeuten i trenings $\varnothing$ kter. Samarbeidet med de pårørende foregikk i form av telefonsamtaler og kontakt når pårørende var på bes $\varnothing \mathrm{k}$. I tillegg var involvering satt i system.

Halvveis i oppholdet møttes pasienten, de pårørende, aktuelle fagpersoner og representanter for besluttende instans i kommunen for å komme frem til en avklaring av oppholdets lengde og innhold, og en omforent konklusjon om det fremtidige tjenestenivået.

\section{«Ansatte involverte pasienter og pårørende både på daglig basis og i planlagte møter.»}

I et lederintervju beskrives samarbeidsformen slik: «Vi ser jo at det er viktig at målene er satt sammen med pasienten, og at ikke vi bestemmer hva som er viktig for dem.»

I samtaler uttrykte de ansatte at de opplevde møtene som vesentlige og krevende. De var opptatt av at både pasienten og de pårørende skulle føle seg ivaretatt, og tilstrebet en balanse mellom deres preferanser og hensynet til en rettferdig bruk av kommunens begrensede ressurser. De lyktes ikke alltid med å nå en omforent konklusjon, og det var ikke alltid mulig å imøtekomme $\varnothing$ nskene til de pårørende.

\section{Samhandle på tvers av nivåene i helsetjenesten}

Korttidsavdelingene hadde utstrakt samhandling med instanser internt i kommunen. Ansatte ved kommunens søknadskontor deltok i de ukentlige tverrfaglige møtene. En beskrev møtet som vesentlig for å få raske og omforente beslutninger om videre forløp, og som en stor forbedring. 
Samhandlingen mellom korttidsavdelingene og andre instanser i kommunen foregikk gjennom skriftlige internmeldinger og telefonsamtaler.

Korttidsavdelingen samhandlet også med sykehus. Inn- og utskriving foregikk digitalt gjennom pleie- og omsorgsmeldinger.

Når det var behov, kom ambulerende team ved sykehusets alderspsykiatriske avdeling til korttidsavdelingen for å samarbeide om enkeltpasienter. Noen pasienter ble innlagt på sykehus, men mye ble håndtert på avdelingene.

Sykehjemslegene hadde omfattende samarbeid om enkeltpasienter med spesialister i sykehus: «Legen er opptatt av å ha en god kontakt med sykehuset, og opplever at leger på begge nivåer har fått flere oppgaver [...] Like etter at møtet har begynt, får legen en telefon fra sykehuset og forlater møtet» (feltnotater).

\section{Maksimere begrensede ressurser}

Den viktigste ressursen på avdelingen var de ansattes samlede faglige kompetanse, og det ble lagt vekt på å heve kompetansen da avdelingene ble omgjort til korttidsavdelinger. Medisinskfaglig kompetanse og rehabiliteringskompetanse var vesentlig for å kunne yte et godt behandlingstilbud og sikre gode pasientforløp.

Enkelte sykepleiere hadde relevant spesialkompetanse, men ifølge en av legene var det utfordrende at den samlede medisinskfaglige kompetansen var begrenset. De hadde utfordringer knyttet til grunnbemanning, sykepleiedekning og akuttmedisinsk kompetanse hos sykepleierne.

\section{«Bemanningsutfordringene ble håndtert ved at alle ansatte var fleksible i det daglige arbeidet.»}


Legedekningen var god, men alle partene opplevde fysioterapitjenesten som utilstrekkelig. Bemanningsutfordringene ble håndtert ved at alle ansatte var fleksible i det daglige arbeidet og ved at bemannings- og kompetansebehovet jevnlig var tema på ledermøter:

«Mesteparten av tiden på møtet ble brukt til å avklare hva man $\varnothing$ nsket å melde inn av behov for høyere bemanning [...] De ble enige om hva de skulle kreve, og bygde sammen opp argumenter og formuleringer» (feltnotater).

Vi observerte at avviksmeldinger ble brukt i argumentasjon for $\varnothing \mathrm{kt}$ bemanning. Ledelsen arrangerte ad hoc-møter for å håndtere forventet overbelegg $\mathrm{i}$ høytider og ferier. Personalets spesialkompetanse var høyt verdsatt, og personalet bidro med å spre sin kompetanse til andre sykehjemsavdelinger og til hjemmetjenestene.

\section{Samhandling fremmer gode pasientforløp}

Da vi oppsummerte fra kategoriene, fremkom dette overordnede temaet.

En mer systematisk arbeidsform medførte nye, tettere samhandlingsmønstre pleiepersonalet imellom og bidro til bedre oversikt, pasientsikkerhet, pasientflyt og derved gode pasientforløp. Den daglige samhandlingen mellom legen og sykepleieren utgjorde kjernen i det tverrfaglige samarbeidet.

I tillegg var ukentlige tverrfaglige møter, der også fysioterapeuten og ergoterapeuten deltok, vesentlige for pasientflyten og gode pasientforløp.

Personalet involverte gjennomgående pasienter og pårørende $\mathrm{i}$ beslutningsprosesser og $\mathrm{i}$ arbeidet mot $\varnothing$ nsket helsetilstand, og la derved til rette for pasientenes eierskap til det videre forløpet. 
Et godt samarbeidsklima bidro til at personalet utnyttet begrensede ressurser og sikret at den samlede kompetansen ble brukt til pasientenes beste.

Disse forholdene viser at avdelingene som helhet arbeidet innovativt med å utvikle tjenestene, og at summen av den samhandlende innsatsen bidro til et best mulig forløp for pasientene (figur 1).

Figur 1. Faktorer som fremmer gode pasientforl $\varnothing p$

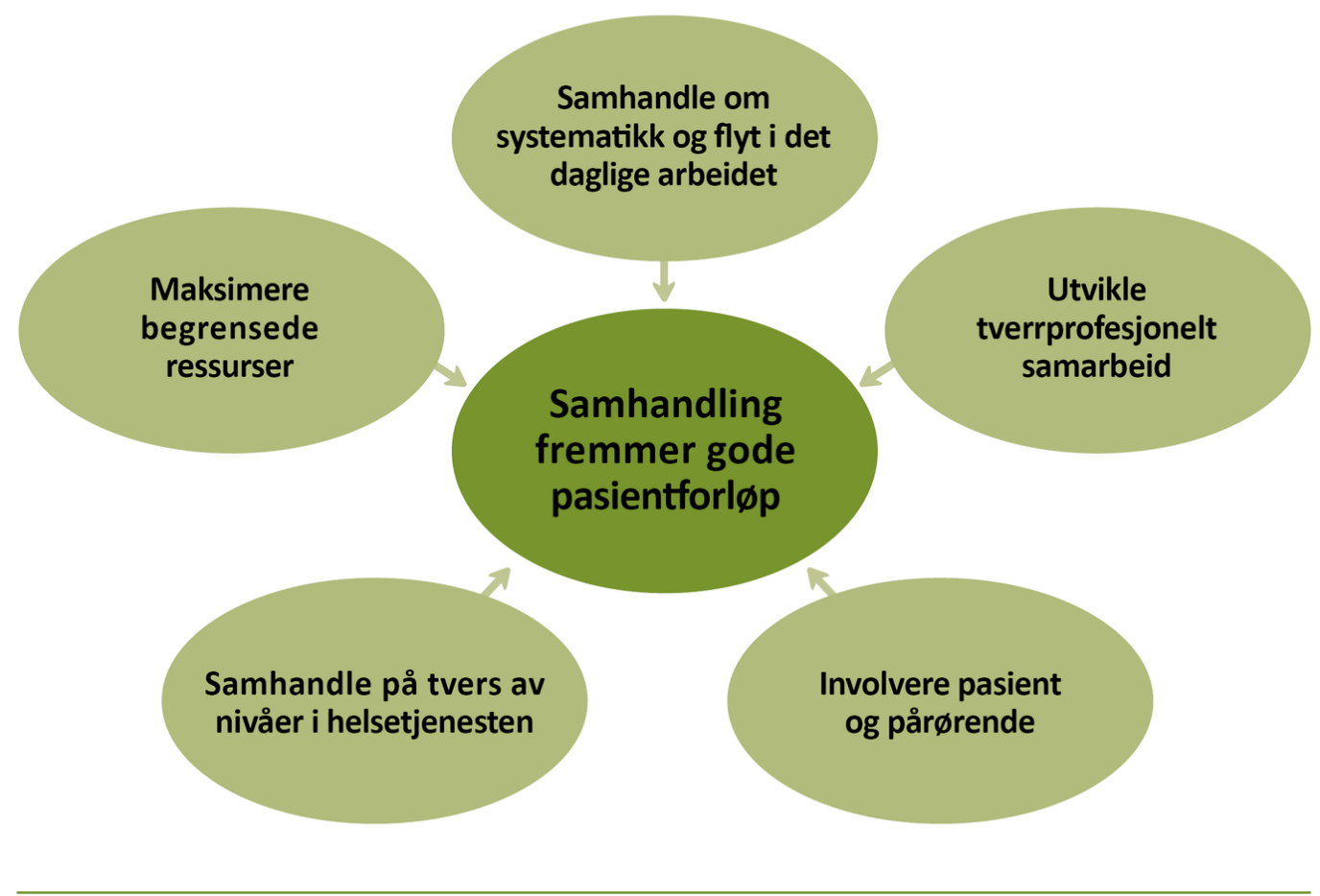

\section{Diskusjon}

Hensikten med denne studien var å utforske faktorer som fremmer gode pasientforløp i korttidsavdeling på sykehjem.

Sykehjemspasienter er særlig utsatt for uheldige hendelser på grunn av deres komplekse, multisyke tilstand (17), og det er grunn til å anta at sikkerheten er ytterligere under press for pasienter som beveger seg mellom ulike tjenestenivåer. 
Allens (14) begrep «forløpskompleksitet» synes

dekkende i denne sammenhengen. Hennes funn viser at systematikk preget både det daglige arbeidet $\mathrm{i}$ pleiegruppen, samarbeidet mellom legen og sykepleieren, det tverrfaglige samarbeidet og samhandlingen med eksterne aktører.

Den systematiske arbeidsmåten er i tråd med faglige anbefalinger om standardiserte pasientforløp og bruk av sjekklister i oppfølgingen (8). Arbeidsmåten synes også å samsvare med det Allen kaller «sikring av pasientforløp»: en praksis som er preget av informasjonsdeling og justering av nødvendige elementer til rett tid og på rett sted (14).

\section{Tverrfaglige teammøter reduserte friksjon}

Det tverrfaglige teamet på avdelingene møttes regelmessig. At tverrfaglige team møtes fysisk, trekkes frem som vesentlig i arbeidet med helhetlige pasientforløp for eldre med kronisk sykdom (9).

Funnene i vår studie viser en tendens til konflikt knyttet til fysioterapitjenesten. Denne utfordringen erkjennes av myndighetene; fysioterapitilbudet på sykehjem er betydelig redusert og mange steder fraværende (18).

Bondevik og medarbeidere (17) fant at pleiepersonalet på norske sykehjem, hovedsakelig sykepleiere, helsefagarbeidere og assistenter, skåret samarbeidet med lege, fysioterapeut og ergoterapeut relativt lavt. I vår studie ble utfordringene søkt løst i det løpende teamarbeidet og gjennom særlige tiltak.

Reeves (19) fremholder at friksjon vil oppstå mellom profesjonsut $\varnothing$ vere, og at formelle og åpne beslutningsprosesser er egnet til å bygge bro og skape tillit og samhold mellom yrkesgrupper.

Overordnet sett viser funnene i vår studie at et vedvarende arbeid for et godt tverrfaglig miljø bidro til at pasienter fikk den hjelpen de trengte til rett tid av dem som hadde den tiltrengte kompetansen. 


\section{Tilbud må ta utgangspunkt i pasientens behov}

Ingstad (13) hevder at pasienten må settes i sentrum for all samhandling hvis målet er helhetlige og gode pasientforl $\varnothing$ p. Dialog med pasienten og de pårørende må bakes inn i organiseringen av tjenestene.

Idealet om brukerorientering er et sentralt element $\mathrm{i}$ moderniseringen av offentlig virksomhet og innebærer at brukernes behov settes i sentrum når tjenestetilbudet utformes (17). Det gjøres ved å ta utgangspunkt i pasientens ressurser, behov og ønsker (9).

Funn i vår studie viser at slike idealer langt på vei ble ivaretatt. Pasientene og de pårørende ble involvert i valg, gjøremål og beslutninger - en praksis som samsvarer med idealene om å legge til rette for helhetlige pasientforløp for eldre med kronisk sykdom $(9,10)$.

Funnene viser at representanter fra kommunens søknadskontor deltok i møtevirksomheten på korttidsavdelingene, og at det var godt samarbeid mellom dem og de ansatte på avdelingene.

\section{«Pasientene og de pårørende ble involvert i valg, gjøremål og beslutninger.»}

Samarbeid med hjemmetjenestene var også satt i system, noe som står i kontrast til funn fra tidligere forskning, der samhandlingen mellom sykepleierne på korttidsavdelingen og søknadskontoret i kommunen var mangelfullt $(6,20)$.

Begreper som «samarbeidspraksis» (21) og «samhandlende praksis» (12) beskriver situasjoner der helsepersonell fra ulike profesjoner samhandler med pasienten, familien og de ulike praksisfellesskapene som pasienten inngår i. 
Kvangarsnes og medarbeidere (6) argumenterer også for at slik praksis kan forstås som innovasjon. Begrepene synes dekkende for den samhandlingen som foregikk mellom aktørene i denne studien.

\section{Samarbeid ga bedre utnyttelse av ressursene}

En kunnskapsoppsummering viser at tilstrekkelig tid og ressurser er viktige i arbeidet med helhetlige pasientforløp for eldre med kronisk sykdom (10). Funn fra studien vår viser at de samlede ressursene ble utnyttet til det beste for pasientene når helsepersonellet, pasientene og de pårørende samarbeidet.

Men det kom også frem at kvaliteten på tjenestene ble utfordret fordi den medisinske og rehabiliterende kompetansen var begrenset. Disse utfordringene gjenspeiles i studier som viser et misforhold mellom ambisjoner for det kommunale tilbudet og personalets kompetanse $(9,22,23)$.

Korttidsavdelinger preges av $\varnothing \mathrm{kt}$ tempo, tøffere vurderinger og større ansvar (6) - trekk ved helseinstitusjoner som er i tråd med Allens begrep «forløpskompleksitet» (14). Avdelingene er også preget av behov for kompetanseheving (6), lav legedekning, lav bemanning, innleie av ufaglært arbeidskraft og mangel på tid (11).

Mye tyder på at det i dag er behov for avanserte kliniske utdanninger for sykepleiere på masternivå, som gir bredere kompetanse enn de tradisjonelle videreutdanningene $(3,12,20,24)$. Slike tilbud vokser frem i Norge og Norden, og leger anser sykepleiere med denne bakgrunnen som en nyttig ressurs (25).

\section{Styrker og svakheter ved studien}

Av forskningsetiske grunner observerte vi ikke på pasientrom eller i møter med pasienter og pårørende. Det kan ha begrenset funnene, særlig de som er knyttet til involvering av pasienter og pårørende. 
En styrke for studiens validitet er at vi arrangerte dialogmøter med ansatte innledningsvis og underveis, og at foreløpige funn ble presentert og validert av ansatte i dialogm øter.

Det kan ha påvirket funnene at alle forskerne er sykepleiere. At forskerne som foretok feltobservasjonene, og forskeren som ikke gjorde det, deltok i analysearbeidet, kan ha bidratt til et kombinert innenfra- og utenfra-perspektiv.

Studien fant sted på to sykehjem som er kjent for innovasjon og god kvalitet. Det kan begrense funnenes gyldighet for organisasjoner som har et annet utgangspunkt. Vi mener likevel funnene kan ha overføringsverdi og være til inspirasjon for miljøer som $\varnothing$ nsker å arbeide innovativt i korttidsavdelinger.

\section{Konklusjon}

Kommunale korttidsavdelinger utgjør et viktig trinn i behandlingskjeden, særlig for eldre som gjennomgår krevende faser med kompleks helsesvikt og usikker fremtid. Å sikre gode forløp i disse situasjonene er viktig og krevende.

Studien viser at samhandling om systematikk og flyt i det daglige arbeidet, utvikling av tverrprofesjonelt samarbeid, involvering av pasienter og pårørende, samhandling på tvers av nivåene i helsetjenesten og maksimering av begrensede ressurser var faktorer som bidro til å fremme gode pasientforløp.

Organiseringen av pasientforløpet krevde samhandlende innsats fra flere aktører. Begrenset bemanning og kompetanse synes å være faktorer å rette oppmerksomheten mot $\mathrm{i}$ klinisk praksis og videre forskning.

\section{Referanser}


1. Rantz ML, Popejoy L, Vogelsmeier A, Galambos C, Greg A, Flesner M et al. Successfully reducing hospitalization of nursing home residents: results of the Missouri Quality Initiative. Journal of the American Medical Directors Association. 2017;18(11):960-6. DOI: 10.1016/j.jamda.2017.05.027

2. St.meld. 47 (2008-2009). Samhandlingsreformen. Rett behandling - på rett sted - til rett tid. Oslo: Helseog omsorgsdepartementet; 2009.

3. Finnbakk E, Skovdal K, Blix ES, Fagerstrøm L. Top-level managers' and politicians' worries about future care for older people with complex and acute illness - a Nordic study. International Journal of Older People Nursing. 2012;7(2):163-72.

4. Helsedirektoratet. Samhandlingsstatistikk 201415. Oslo: Helsedirektoratet; 2016. Tilgjengelig fra: https://helsedirektoratet.no/publikasjoner/samhandlin gsstatistikk (nedlastet 03.10.2019).

5. $\quad$ Tingvold L, Magnussen S. Økt spesialisering og differensiering i sykehjem. Hvordan løses dette i ulike kommunale settinger? Tidsskrift for omsorgsforskning. 2018;4(2): 153-64.

6. Kvangarsnes M, Hole T, Teigen S, Teige BK. Samhandlande praksis som innovasjon. Erfaringer med $\varnothing y e b l i k k e l i g$ hjelp døgnopphald i kommunar i rurale strøk. I: Kvangarsnes M, Håvold JI, Helgesen $\varnothing$, red. Innovasjon og entreprenørskap - Fjordantologien. Oslo: Universitetsforlaget; 2015.

7. Bruvik F, Drageset J, Abrahamsen JF. Fra sykehus til sykehjem - hva samhandlingsreformen har ført til. Sykepleien Forskning. 2017;12(60613):(e-60613). DOI: 10.4220/Sykepleienf.2017.60613 
8. Dale B, Folkestad B, Førland O, Helles $\varnothing$ R, Moe A, Sogstad M. Er tjenestene fortsatt «på strekk»?: om utviklingstrekk i helse- og omsorgstjenestene i kommunene fra 2003 til 2015. Senter for omsorgsforskning; 2015. Rapportserie nr. 12/2015.

9. Danielsen KK, Nilsen ER, Fredwall, TE. Pasientforløp for eldre med kronisk sykdom. Omsorgsbiblioteket. Senter for omsorgsforskning, sør: 2017.

10. Pedersen KR. Hvilke kunnskapsmessige utfordringer ligger i sykepleiernes arbeid på en korttidsavdeling i sykehjem? [masteroppgave]. Troms $\varnothing$ : Universitetet i Troms $\varnothing$, Det helsevitenskapelige fakultet, Institutt for helse- og omsorgsfag; 2012.

11. Killie PA, Debeasay J. Sykepleieres erfaringer med samhandlingsreformen ved korttidsavdelinger på sykehjem. Nordisk tidsskrift for helseforskning. 2016;12 (2). DOI: $\underline{10.7557 / 14.4052}$

12. Bukve $\mathrm{O}$, Kvåle G, red. Samhandling og kvalitet i helseorganisasjoner. Oslo: Universitetsforlaget; 2014.

13. Ingstad K. Organisasjon og ledelse i helsefag og sykepleie. Oslo: Gyldendal Akademisk; 2010.

14. Allen D. Care trajectory management: a conceptual framework for formalizing emergent organisation in nursing practice. Journal of Nursing Management. 2018;27(1):4-9. DOI: 10.1111/jonm.12645

15. Polit DF, Beck CT. Nursing research: generating and assessing evidence for nursing practice. 10. utg. Philadelphia: Wolters Kluwer; 2017.

16. Graneheim UH, Lundman B. Qualitative content analysis in nursing research: concepts, procedures and measures to achieve trustworthiness. Nurse Education Today. 2004;24(2):105-12. DOI:

10.1016/j.nedt.2003.10.001 
17. Bondevik GT, Hofoss D, Husebø BS, Deilkås ECT. Patient safety culture in Norwegian nursing homes. BMC Health Services Research. 2017;17:424.

18. Willumsen E, Ødegård A, red. Tverrprofesjonelt samarbeid - et samfunnsoppdrag. Oslo:

Universitetsforlaget; 2016.

19. Meld. St. 26 (2014-2015). Fremtidens primærhelsetjeneste - nærhet og helhet. Oslo: Helseog omsorgsdepartementet; 2015.

20. Reeves. Sosiologisk forstålse av tverrprofesjonell utdanning og praksis. I: Willumsen E, Ødegård A, red. Tverrprofesjonelt samarbeid - et samfunnsoppdrag. Oslo: Universitetsforlaget; 2016. s. 146-61.

21. Myhr HR. Tverrfaglig samarbeid i et helhetlig pasientforløp - en studie av beslutningsprosesser i et kommunalt tverrfaglig team [masteroppgave]. Trondheim: Norges teknisknaturvitenskapelige universitet, Fakultet for samfunnsog utdanningsfag, Institutt for sosialt arbeid; 2017. Tilgjengelig fra: http://hdl.handle.net/11250/2569316 (nedlastet 24.02.2020).

22. Willumsen E, Sirnes T, Ødegård A. Nye samarbeidsformer - et samfunnsoppdrag. I: Willumsen E, Ødegård A, red. Tverrprofesjonelt samarbeid - et samfunnsoppdrag. Oslo: Universitetsforlaget; 2016. s. 17-32.

23. Bing-Jonsson P, Foss C, Bjørk IT. The competence gap in community care: imbalance between expected and actual nursing staff competence. Nordic Journal of Nursing Research. 2015;36(1):27-37.

24. Kyrkjeb $\varnothing$ D, Søvde BE, Råholm M-B. Sjukepleiarkompetanse i kommunehelsetenesta: Er det rom for fagleg oppdatering? Sykepleien Forskning. 2017;12(64027):(e-64027). DOI: $\underline{10.4220 / \text { Sykepleienf.2017.64027 }}$ 
25. Hauge S, Hestetun M, Kirkevold M. Avansert geriatrisk sykepleie - hva er det og hvorfor trenger vi slike sykepleiere i Norge? Geriatrisk sykepleie. 2011;3(1):20-3.

26. Smailhodzic E. Behov for avansert kliniske sykepleiere innen eldreomsorgen i Norden. En kvalitativ studie ut fra legens perspektiv [masteroppgave]. Høgskolen i SørøstNorge, Fakultet for helsevitenskap; 2016. 